Institute of $\mathbf{F}_{\text {ood and }} \mathbf{A}_{\text {gricultural }} \mathbf{S}_{\text {ciences }}$

\title{
Biological Control for Insect Management in Strawberries ${ }^{1}$
}

\author{
Silvia I. Rondon, Daniel J. Cantliffe, and James F. Price ${ }^{2}$
}

The strawberry, Fragaria ananassa Duch., is an intensively cultivated high value crop that requires inputs of chemicals, including insecticides and miticides. Through early identification of arthropod problems, and targeted releases of reared beneficial insects and mites, it may be feasible to minimize the requirements for pesticides on strawberry.

\section{Integrated Pest Management and Crop Scouting}

Integrated pest management (IPM) is a holistic approach to pest control in which different practices are implemented even before planting the crop. Some of these practices include sanitation, setting plants or plugs which are free of pests, sound cultural practices (soil solarization, field selection, pruning), and applying environmentally friendly pesticides compatible with biological control agents.

Crop monitoring is the foundation of IPM programs because it provides awareness of pest presence, activity, and movement. Monitoring data addresses the needs of the crop and targets pest problems by reducing pesticide use or eliminating routine applications. The goal of monitoring is to locate and identify insects, mites, and disease problems. Weekly random plant inspections throughout the crop area should be performed. Visual counts or the use of traps, such as yellow or blue sticky traps (Fig. 1) which are commercially available, are strongly recommended. Most insect adults are attracted to the yellow or blue color of traps. These traps are sheets coated on both sides with a sticky non-toxic compound. Traps can be used for detecting presence of arthropods or for mass trapping of pests such as aphids, thrips and others. Indoor, traps can be hung from galvanized wire stakes or placed in plant containers; outdoor traps can be hung from fence stakes. Traps should be located at canopy level, and the number of traps will depend on the area planted and pest type. Some recommendations suggest 1 trap per $900 \mathrm{~m}^{2}$ for detection and up to 10 or more per $900 \mathrm{~m}^{2}$ for control. Some places where you can buy sticky traps: Bioquip (17803 LaSalle Avenue, Gardena, CA 90248) and Gemplers' (PO Box 270, Belleville, WI 53508).

Traditional control methods will vary according to where the crops are produced: greenhouse or field. In greenhouses, control methods such as physical (control of heat and humidity, light intensity), mechanical (screens, hand destruction), chemical (pesticides), and biological control (introduction of

1. This document is HS923, one of a series of the Horticultural Sciences Department, Florida Cooperative Extension Service, Institute of Food and Agricultural Sciences, University of Florida. Publication date: June 2003. Please visit the EDIS Web site at http://edis.ifas.ufl.edu.

2. Silvia I. Rondon, postdoc, Daniel J. Cantliffe, professor and chair, Horticultural Sciences Department; James F. Price, associate professor, GCREC-Bradenton, Cooperative Extension Service, Institute of Food and Agricultural Sciences, University of Florida, Gainesville, 32611. 


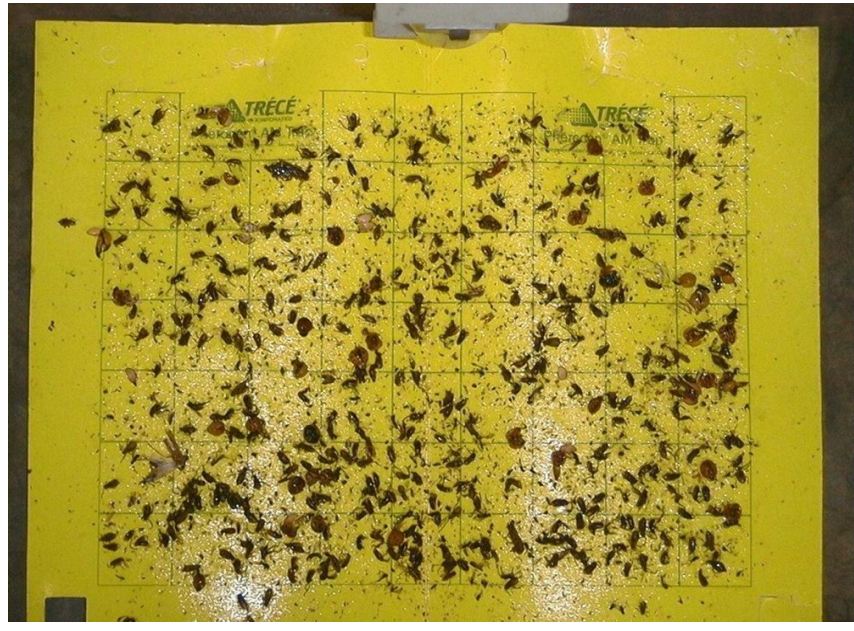

Figure 1. Some insects are attracted to yellow sticky traps.

parasitoids and predators) are effective and will determine the success of the crop. In the field, cultural (sanitation, weed control), chemical (more variety of registered chemicals) and biological control (habitat manipulation, introduction, augmentation), can all contribute to effective pest control.

\section{IPM Program for Strawberry Production}

In the Protected Agriculture Greenhouse Project of the Horticultural Sciences Department at the University of Florida

(www.hos.ufl.edu/ProtectedAg/), we are developing an IPM program for strawberry which emphasizes the use of living agents for insect biological control not only for greenhouse strawberry but also for field production. Biological control is defined as the suppression or destruction of undesirable pests by the introduction, encouragement, or artificial increase of beneficials (parasitoid, predators, and/or pathogens). Some of the beneficials that can be used on strawberry crops are listed below in Table 1 .
Chemical methods also are an option when pests (insects and diseases) surpass established economic thresholds (edis.ifas.ufl.edu/PI037). However, the use of pesticides compatible with biological control agents is critical (www.koppert.nl/e0110.html).

The twospotted spider mite has a well developed management plan. Some of the elements include the use of high quality transplants, inspection of transplants, and release of predators. The leaves of one transplant per bundle should be examined and if mites are found, the immediate release of Phytoseiulus persimilis predatory mites is recommended. After planting, there are two methods to approach mite control: biological control with predatory mites and chemical control with miticides. Predators should be released at one mite per transplant as soon as 8-10\% of sampled leaflets have a spider mite or egg (Price personal communication). If mites exceed the threshold, then miticides can be applied. Products such as Savey ${ }^{\circledR}$, Acramite ${ }^{\circledR}$, Agri-Mek ${ }^{\circledR}$, and Vendex $®$ are recommended. Selection of chemicals compatible with biological control of the spider mite is possible.

\section{Generalist Predators}

Predators are free living organisms that immediately kill their prey by direct attack. The project is currently studying the possibility of integrating generalist predators into the strawberry ecosystem. These include: the pink spotted lady beetle (PSLB), Coleomegilla maculata De Geer (Fig. 2), the big-eyed bug, Geocoris punctipes (Say) (Fig. 3), and the minute pirate bug, Orius insidiosus Say (Fig. 4). The targeted pests are the melon aphid, Aphis gossypii Glover, the twospotted spider mite, Tetranychus urticae Koch, the flower thrips,

Table 1. Some of the beneficials (parasitoid, predators and/or pathogens) that can be used on strawberry.

\begin{tabular}{||l|c|c|c||}
\hline \hline \multicolumn{1}{|c|}{ Pests } & Biological Agents & Common Name & Category \\
\hline Western flower thrips & Neoseiulus cucumeris & Cucumeris & Predator \\
& Orius insidiosus & Minute pirate bug & Predator \\
\hline Cotton or melon aphid & Hippodamia convergens & Lady beetle & Predator \\
& Coleomegilla maculata & Lady beetle & Predator \\
& Chrysoperla rufilabris & Chrysopa & Predator \\
& Aphidius colemani & Aphidius wasps & Parasitoid \\
\hline \hline
\end{tabular}


Table 1. Some of the beneficials (parasitoid, predators and/or pathogens) that can be used on strawberry.

\begin{tabular}{|l|c|c|c||}
\hline \multicolumn{1}{|c|}{ Pests } & Biological Agents & Common Name & Category \\
\hline Twospotted spider mites & $\begin{array}{c}\text { Phytoseiulus persimilis } \\
\text { Neoseiulus californicus }\end{array}$ & Persimilis \\
& Cacilifornicus & Predator \\
& & Predator \\
\hline Caterpillars & & others & Pathogen derived \\
\end{tabular}

Frankliniella spp., and sap beetles (Carpophilus spp., Lobiopa insularis (Castelnau)).

The North American native pink spotted lady beetle (PSLB) is a medium-sized (about 5-6 mm), pink to red and oval beetle, with six spots on each forewing (Fig. 2). It can be found on a variety of crops such as wheat, sorghum, alfalfa, soybeans, cotton, potatoes, sweet corn, peas, beans, tomatoes, asparagus, and other crops. Adults and larvae are important agents for control of aphids, mites, insect eggs, and small larvae. Unlike most lady beetles, plant pollen may constitute up to $50 \%$ of the diet, thus, the planting or preservation of refugia of flowering species will be beneficial to provide additional food. The female lady beetles lay approximately 200 eggs during their life span (Rondon personal observation). Eggs are deposited near prey in small clusters (12-15 eggs/cluster) on leaves and stems. Larvae grow to 5-6 mm (4 instars) in length. The pupal stage may last 3 to 12 days depending on temperature (Wright and Laing 1982).

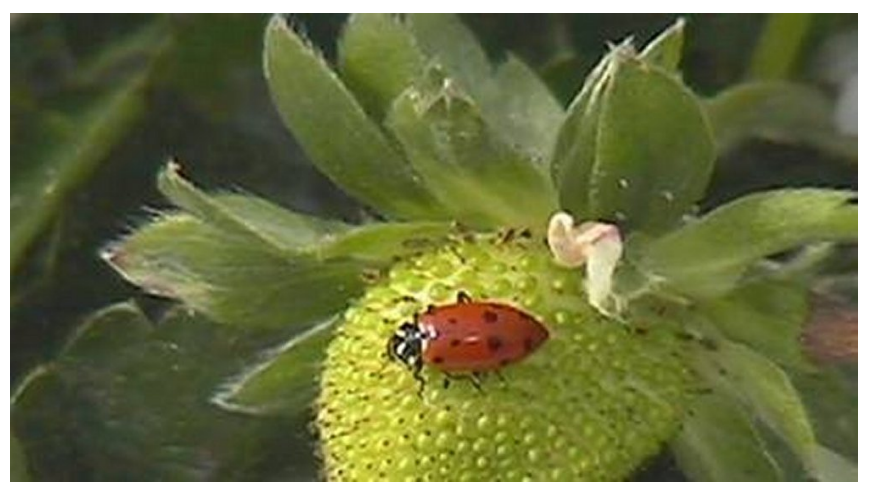

Figure 2. Coleomegilla maculata in a strawberry fruit.

The big-eyed bug (Fig. 3) feeds on a variety of prey including mites, aphids, chinch bugs, whiteflies, small caterpillars, thrips, Lygus bugs, psyllids, and eggs of other pests. Both adults and immatures can consume dozens of prey per day. They are among the most important natural enemies in cotton. Adults live approximately one month and a female can lay up to 300 eggs during her adult life span (Van Driesch and Bellows 1996). The eggs are pinkish and oblong, and the nymphs are bluish-gray with beautiful prominent eyes. Nymphs develop through five nymphal instars, are wingless, and remain in an area with prey to feed and to develop into adulthood (Champlain and Sholdt 1967).

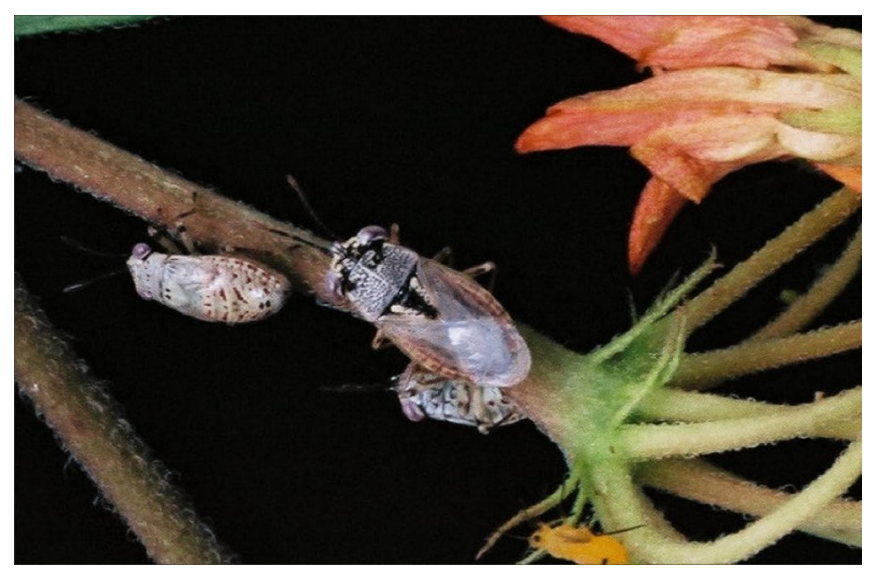

Figure 3. Adults and nymphs Geocoris punctipes.

The minute pirate bug (Fig. 4) is very small (3 $\mathrm{mm}$ long), oval-shaped, and black with white wing patches. Nymphs are also small, wingless, and yellow-orange to brown. Both adults and nymphs feed by sucking juices from their prey through a sharp, needle-like beak. They are common inhabitants of cotton, peanuts, alfalfa, corn, pea, and strawberry (Askari and Stern 1972). The minute pirate bug has been successfully used as a biological control agent in greenhouses and open fields. Immature stages (nymphs) and adults feed on a variety of small prey including thrips, spider mites, aphids, small caterpillars, and eggs of other insects. Females lay tiny eggs after mating within plant tissues where they are not easily seen. The eggs hatch into nymphs which develop through five nymphal stages. A female lays approximately 129 eggs during her life span, and adults live about 35 days (Van Driesch and 
Bellows 1996). Immature and adult minute pirate bugs can consume 30 or more spider mites per day.

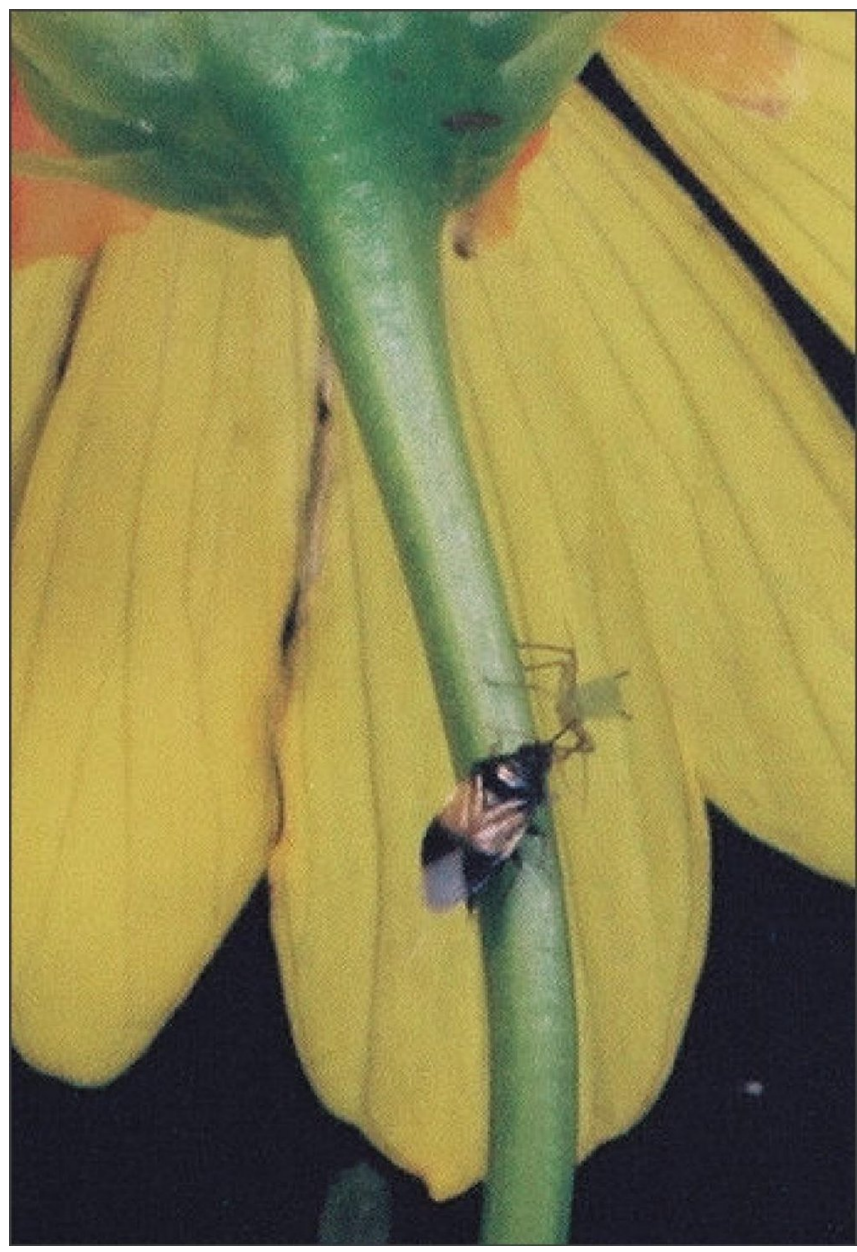

Figure 4. Orius insidiosus feeding on an aphid.

These predators are commercially available through members of the Association of Natural Biological Control Producers (ANBP) (www.anbp.org/index.htm) and through private companies.

\section{Total Integrated Pest Management}

A strawberry IPM suggested protocol includes:

\section{Cultural Control}

\section{Before planting}

- Select high quality transplants

- Variety selection: avoid varieties highly susceptible to pests
- Transplants should be inspected and be free of pests

- Releases of beneficials if needed

2. After planting

- Site selection: avoid planting crop close to woody areas

- Early release of beneficial if needed

II. Cultural Control while maintaining the crop

1. Weed removal from edges

2. Prompt removal of crop residues

3. Remove debris that may shelter pests

\section{Scouting \\ 1. Before blooming (once per week) \\ 2. During bloom (once per week) \\ 3. Post bloom (once per week)}

Following adequate sanitation, elimination of crop residues, detecting early infestation of pests, and releases of beneficials, can be sufficient to keep level of arthropods below the economic injury level. Secondary pests such as sap beetles should not be overlooked. Correct identification and cultural control are key in sap beetle control. Sanitation and early and thoroughly harvesting decrease sap beetle population (Potter 1985). The predators, PSLB and the minute pirate bug, will be an important addition to the biological control complex already in existence in the strawberry crop ecosystem (predatory mites and wasps). These predators could lead to the reduction of arthropods pests of strawberry pests; as a consequence, the use of insecticides or miticides in the strawberry might decrease. This reduction in chemical dependency will create a healthier environment, reduce crop re-entry constraints, reduce hazards to pesticides applicators and other workers, and will encourage consumers to purchase strawberries. 


\section{Literature Cited}

Askari, A. and V.M. Stern. 1972. Biology and Feeding habits of Orius spp. (Hemiptera:

Anthocoridae). Ann. Entomol. Soc. Amer. 65:

96-100.

Champlain, R.A., and L.L. Scholdt. 1967.

Temperature Range for Development of Immature

Stages of Geocoris punctipes (Hemiptera:

Lygaeidae). Ann. Entomol. Soc. Amer. 60: 883-885.

Potter, M.A. 1995. The Nitidulidae (Coleoptera)

Associated with Strawberry Eastern Hillsborough

County, Florida. Thesis. MS. University of Florida.

Pp 98.

Van Driesh, R.G.V., and T.S. Bellows. 1996.

Biology and Arthropod Parasitoids and Predators. Pp.

309-335. In Biological Control. Chapman and Hall,

International Thompson Publishing, NY. 